\title{
Design Thinking and its visual codes enhanced by the SiDMe Model as strategy for design driven innovation
}

\author{
Ribas-Fornasier, Cleuza ${ }^{a}$; Perfecto-Demarchi, Ana-Paula ${ }^{b}$ \& de Freitas Martins, Rosane \\ ${ }^{a} \mathrm{PhD}$, Associate Professor at Universidade Estadual de Londrina - Brasil. cleuzafornasier@gmail.com \\ ${ }^{\mathrm{b}} \mathrm{PhD}$, Associate Professor at Universidade Estadual de Londrina - Brasil. perfeto@sercomtel.com.br \\ ${ }^{\mathrm{c}} \mathrm{PhD}$, Assocaite Professor at Universidade Estadual de Londrina - Brasil. rosane@uel.br
}

\begin{abstract}
The society is changing, leaving the old paradigm of work to a new one that is more dynamic and complex. In this context the way that the people consumes chance. In order to survive this scenery the companies has to innovate, but not only innovate based in the behaviours of the actual users, but innovate based in a person and its relations that do not exist yet, therefore the companies have to adopt the design driven innovation which brings advances dealing with knowledge of visual codes and meanings. This article aims to demonstrate how the model Strategic Integrator Design Management enhanced (SiDMe), which treat the design as a knowledge and adopt the design thinking, can lead companies to adopt incremental and radical innovation through design driven innovation. To do so it will discourse about the design driven innovation, design Thinking and present the SiDMe conceptual model. This research will work with the ex-post-facto delineation, using ethnography as a strategy, through the non-participant observation. After the application of the model it is evident that by the application of Design Thinking it will be able to help the companies to achieve incremental and radical innovation by the design driven innovation.
\end{abstract}

Keywords: Design Driven Innovation; visual codes; Design Thinking; Design Management 


\section{Introduction}

Now a days, the design is recognized as an innovation strategy, because by all meaning it is an innovation activity. Consumers increasingly are in control of their own consumption, and are aware of the value (aesthetic, symbolic and emotional) of the product, which is transmitted by the design language (a combination of forms, signs, colours, materials - all that give meaning to a product) that has mobilized companies to employ efforts to define appropriate strategies (or suitability) of the design language to its products, as the design itself is seen as differentiation strategy as it is responsible for the form attributed to the brand, products and processes, which in turn equates to a proposition to be interpreted. Romanini (2008) found that articulate signs to reach pragmatic communicative effects is the essence of Design.

Among these strategies (including sort by signs) and innovative processes, an approach has gained space: design thinking. Brown (2009) states that the Design thinking benefits from the human ability to be intuitive, empathic, recognize patterns, develop ideas that have an emotional meaning as well as functional, and that be able to express themselves in medias beyond words or symbols (capacity forgotten by conventional resolution practices problems). It is a human proposed by the nature and not merely centred in humans.

Nowadays, to address this consumer/author at the speed that it requires, with its different way of thinking ( its ability to choose, interpret, freely combine services, products and aesthetic), and whose meaning is relates to new values and experiments, manifested by behavior and suggested parameters and supported by new technologies (Morace, 2009). Organizations, eager for innovation, and despite its high cost and time investments, has taken the risk of adopting radical, or incremental innovation.

The technology driven innovation is often difficult to achieve, thus organizations start to look for the design driven innovation, in other words, focused on meaning.

Designers have expanded their action, leaving the traditional position of developing processes and products, which address issues like style and ergonomics, for a greater contribution in generating new concepts and management of the image (in the broad sense) around these concepts. For this, use the empathic observation skills to understand the consumer's requirements (users / authors / viewers) as well as it relations.

The Strategic Integrator Design Management enhanced (SiDMe) presented here is a conceptual model based on design thinking, that will assist the designer in its new role, enhancing its skills, becoming a tool for design driven innovation (Demarchi, A.P.P., Fornasier, C.B.R. \& Martins, R.F.F. , 2013).

\section{Innovation}

Terra et al. (2007) claims that "innovation means having a new idea or, apply the idea to others in a way that is original and effectively". But not only: it is a new idea combined with implementation, or successfully exploitation of new ideas.

There are many kinds of innovation. The classifications vary according to the object of innovation. In this papers we will adopt the classifications of Higgins coated by Xavier (2014) that specified tree levels of innovations: Incremental, Semi radical and Radical.

- Incremental innovation is prevalent in most companies. It is small and practical changes that can be applied in business models, products or services.

- Semi radical: compared to incremental innovations, this can leverage major changes involving changes in the business model or on the company's technology.

- Radical: consists of changes in the business model and technology of the company and usually cause significant changes in the market. It is possible that radical innovation is followed by other levels of innovations that cause improvement in the product.

Another classification of innovation, stated by Chesbrough (2012), is related to this paper is the one that differentiate the close and open innovation: 
- The closed innovation is an approach that is fundamentally focused inward, and well suited to early 20th-century paradigms.

- Open innovation is the paradigm that assumes "that companies can and should use external ideas in the same way that use internal ideas, and internal and external paths to market" (Terra, 2007). This classification adapts to 21 st century paradigms.

In the 21st Century the ideas cannot remain in stock on the shelf, because it will end up leaking to the larger environment. It need this larger environment to co-create, and be brought back to the organization to be transformed into new products and services. It is observed that the knowledge they're not centralized in research facilities, but are groupings of varied knowledge distributed throughout scenario.

Therefore, companies are practicing new opportunities for innovation. The 21 st century is the century of open innovation, so we will demonstrate a model that through the co-creation (emphasizing the open innovation) generate radical and incremental design driven innovation based on Design Thinking.

\subsection{Technology driven innovation $X$ Design Driven innovation}

Having introduced some basic concepts of innovation, we can now understand the concept technological and meaning innovation. Technology driven innovation brings technological advancement, uses technological knowledge. Meaning driven Innovation is based on the meanings, uses knowledge of languages and meanings, the design is comfortable with these knowledge.

Norman and Verganti (2012) claims that the organizations in this century seek either incremental or radical innovations. They affirm that usually the radical innovation is achieved by the technological knowledge, however it is costly and take too long to develop a radical innovation by technological knowledge. In a complex society, where the time and space change so rapidly we don't have room for that.

The author's suggest a two dimension model that demonstrate how an organization can achieve radical innovation using the meaning and languages knowledge. The figure 1 below demonstrate this model.

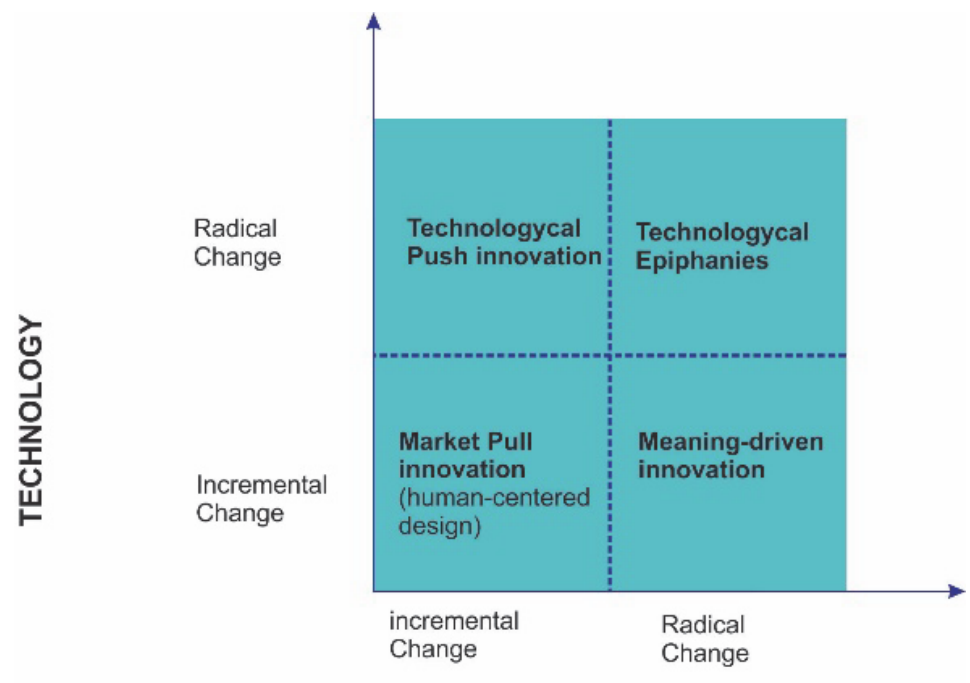

MEANING

Fig. 1 The two dimensions and four types of innovation. Source: Norman \& Verganti $(2012$, p.12) 
We can observe that the human centered design can only create incremental innovation. This is because according with Norman and Verganti (2012) it starts from the analysis of user needs and them develops products to satisfy them. Most of the processes of design works in this way.

The technological push innovation comes from radical changes in technology without any change in the meaning. Norman and Verganti (2012) affirm that because it definitely does not come from users, most of the time is not accept by those.

The technology Epiphanies uses a new technology or the use of existing technology in a totally new context. Its happen "when the design challenges the dominant interpretation of what a product is and create new, unsolicited product the people are not currently seeking" (Norman and Verganti , 2012.)

Mening-Driven innovation "starts from the comprehension of subtle and unspoken dynamics in sociocultural model and result in a radically new meaning and languages, often implying a change in a socialcultural regime" (Norman and Verganti, 2012).

All these kinds of innovation, in some degree, need to understand the market dynamic, the people aspiration, and some of them need to explore new technology. It is clear that for a successful project is necessary to pay attention on the starting point.

As we can see, radical innovation may be associated with change in either technology or meaning. But how can the design help the organizations to lead to these types of innovations?

Verganti (2010) states that "designers give meaning to products by using a specific design language that is the set of signs, symbols and icons (of which style is just an instance) that deliver the message".

Based in this definition we can link more precisely design with other theories of innovation. Consider in particular the Figure 2, we may say that innovation may concern a product's functional utility, its meaning or both.

In particular, innovation of meanings is incremental when a product adopts a design language and delivers a message that is in line with the current evolution of socio-cultural models. Users would probably perceive this product as "fashionable" and maybe stylish as it conforms to existing definitions of beauty, i.e. with a style that leverages on accepted languages. However, innovation of meanings may also be radical, which happens when a product has a language and delivers a message that implies a significant reinterpretation of meanings.

Verganti (2010) mapped three modes of innovation in a two dimension model that relates Functional utility and meaning as demonstrated on figure 2 .

The first is Design driven innovation that starts with understanding the subtext and the dynamics not spoken in sociocultural model and results in the radical proposal of new meanings and languages that often imply cultural regime change, however it may not change, so this mode can generate radical or incremental innovation. Note that design driven innovation sometimes is not immediate. It takes time to diffuse and achieve acclaimed success. Users indeed need to understand the radically new language and message, find new connections to their socio-cultural context, explore new symbolic values and patterns of interaction with the product.

The second is Market pull innovation, which starts with the analysis of the needs of users and search for technologies and languages that may meet it. User-centered innovation is allocated in this strategy, despite being more advanced and sophisticated in its technologies, allowing a better understanding of why and how people give meaning to things, its only achieve incremental innovation. 


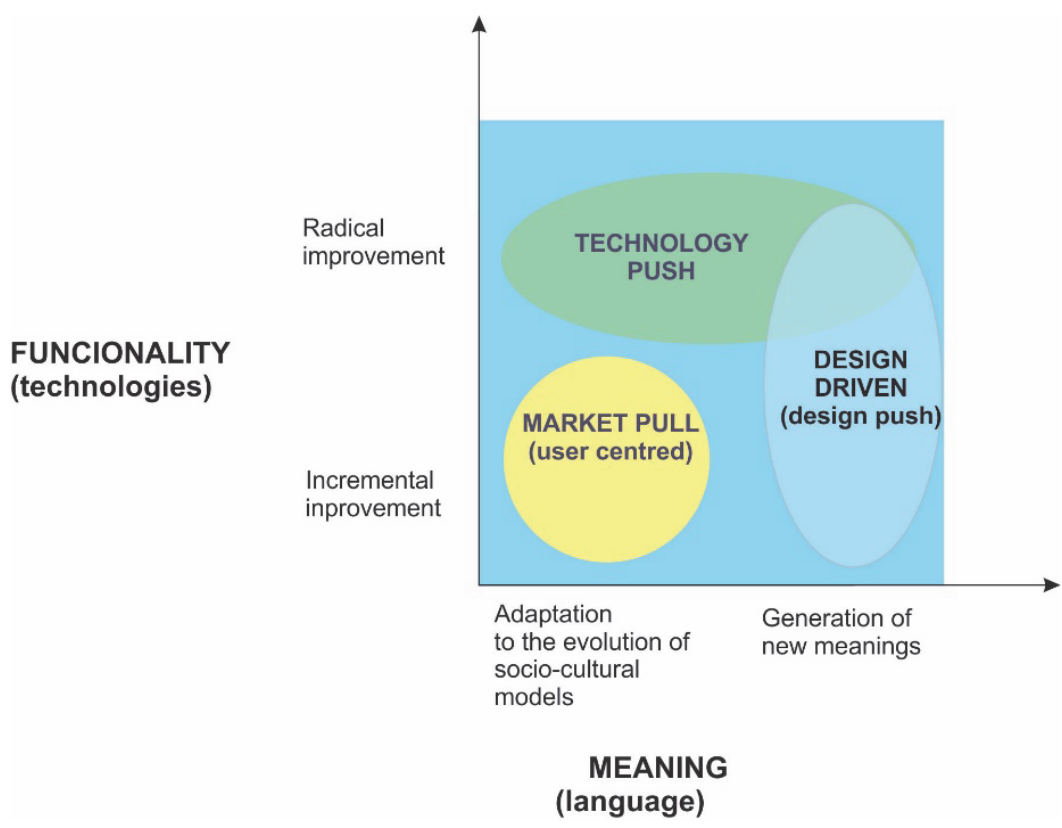

Fig. 2. Innovation strategies. Source: Verganti (2010 p.17)

Finally, the technology driven Innovation. The overlap between the technology driven and design driven, in the upper right corner of the diagram, demonstrates that advances in technological changes are often associated with the radical changes of meaning of the product, i.e. changes in the technological paradigm are often aligned with changing socio-cultural systems.

To cope with the design driven innovation requires a capability to understand, anticipate, propose and influence the emerging of new meanings. The knowledge about the subtle and not expressed-cultural model dynamics are tacit is not codified in books or in sociological scenarios of the future, and this knowledge is distributed. The modeling of socio-cultural model and their impact on the interpretation of the language of the products depends on millions of unpredictable interactions between users, businesses, designers, products, cultural centers, communicational media, schools, artists, among others.

"Design driven innovations are not answers to user needs, but proposals. They explicitly recognize their action as possibly driving change in socio-cultural regimes. Design driven innovation is therefore a pushing innovation activity, a proposal of possible breakthrough meanings and product languages with a high chance of diffusion in future society" (Verganti, 2010 p. 15)

The Design Thinkers value the interaction with this network of actors. They consider these actors as interpreters of the evolution of the future scenario, with which they share their own visions, exchange information on trends and test the robustness of your assumptions.

We must not confuse the user centred innovation with design driven innovation. The first focuses only on an actor, the user, and does not attempt to understand how it assigns meaning to things. The second works with actors and focuses on their relationships to understand how it assigns meaning, to be able to change the meanings.

Verganti called these relationship network of design discourse, "a collective research of meaning and design languages process, i.e. a continuous dialogue on socio-cultural models (foreseen and desired) and its implications on patterns of consumption and product languages, occurring through several explicit and tacit interaction among several actors in the global and local setting" (Verganti, 2010 p. 22).

This process differs from the user centred approach, as much by nature as by players (Figure 3 ). The basic characteristics of this approach are: 
- A network search process (open innovation).

- Beyond the boundaries of the company, including users, but also several other interpreters.

- Based on the sharing of knowledge.

- Also includes the action of influencing and a social-cultural regime modification.

\section{USER CENTRED DESIGN}
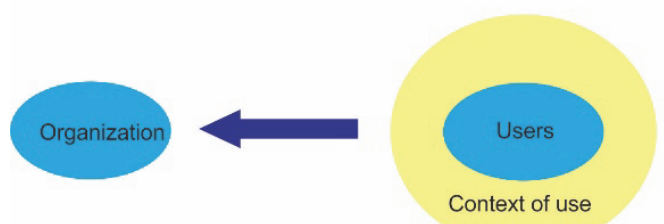

NOW

\section{DESIGN DRIVEN INNOVATION}

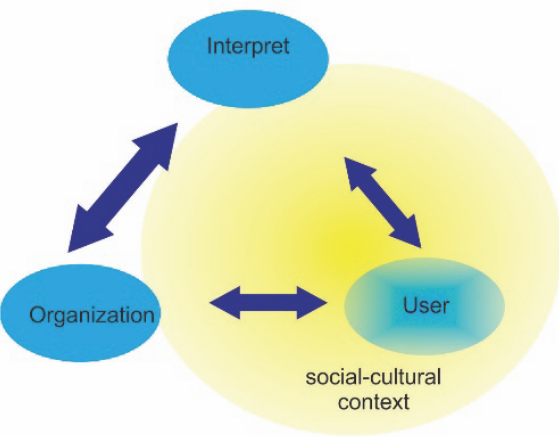

FUTURE AND

PAST

Fig. 3. User centred design and design driven innovation. Source: Verganti (2010 p.22)

The key capability in the user-centered design approach, elicit their needs and be creative in finding solutions. The key capacity in design driven innovation is accessing and sharing knowledge using the design discourse, and more precisely, identify the key performers, to attract them and develop with them a privileged relationship, to share knowledge and recombine and so build a unique proposal.

To the use of the design driven innovation in companies is necessary to access and internalize knowledge of the design discourse, for which requires the design thinker, which became the interpreters of the discourse of design, and all his skills is used to help the organization to have access to that speech (the design).

The design thinker possesses different skills that often are not present in a person. Sometimes these skills help in building links between the different socio-cultural worlds and the industries, and to facilitate the transfer of knowledge of meanings and languages between different contexts. Design driven Innovation call these people as gate keepers. They facilitate the access of the designer to users to bring knowledge about design's languages to the process, and help customers to interpret the design discourse, and to position themselves in this speech.

The key characteristic in the design driven innovation is that designers act as a cross-pollinators of knowledge in languages and technologies.

We can highlight that access to external information should not be restricted only to the gatekeepers, but to the entire organization. So the organization must have the capability to absorb, to understand and assess external knowledge, make sense, and learn, and then adopt new approaches. Open innovation and the skills of design thinker, should be adopted as they may assist the organization to build the absorption capacity.

Based on the foregoing, we may accept that the design process is a process full of knowledge, that to be extracted and shared is necessary the use of the skills of design thinker. We may now understand which skills are those. 


\section{Design Thinkers skills and the Innovators DNA}

The conceptual model shown in this article is intended to assist the process of design driven innovation in organizations by using some skills of design thinkers.

Dyer, Gregersen \& Christensen (2011) agree that innovation is triggered by the skill that innovators have to unite ideas (call this cognitive ability of associative thinking), however, innovators think not only different, but also act differently. Some observe the world with an intensity greater than ordinary people. Others create networks with other people creating a collaborative group, while others engage in experimental actions. Innovation and creativity is not just a cognitive ability, but also a matter of behavior.

Creativity is the gear for innovation and have to be practiced. It is a natural human ability, but we lose as we grow up, maybe by shyness or fear of criticism. The authors assume that creativity is a combination of idea plus courage.

They have created a model that demonstrates the innovative DNA to generate innovative ideas, shown in Figure 4, below.

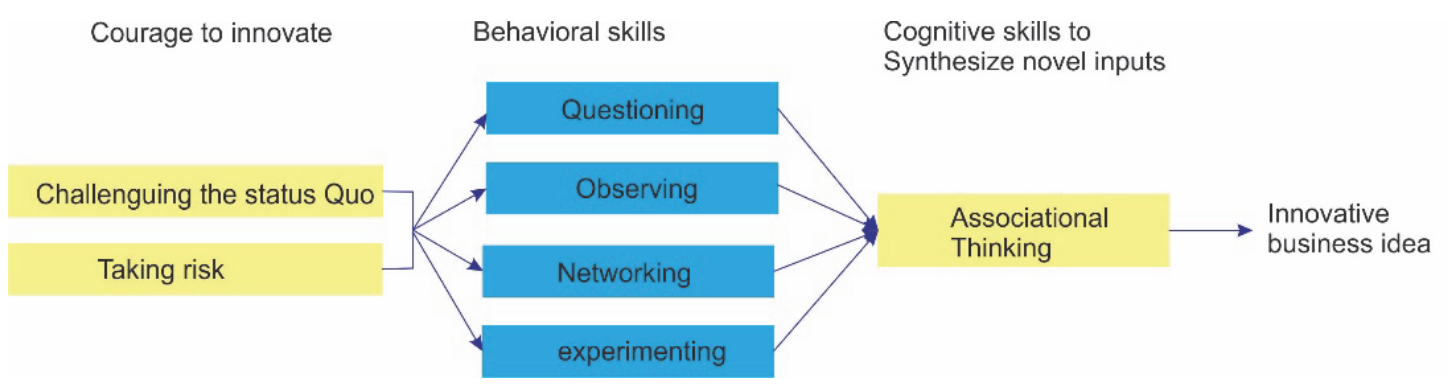

Fig. 4. Innovator's DNA Model. Source: Dyer, Gregersen e Christensen (2011, p.27)

The courage to innovate, is similar to the Design Thinkers attitude. Martin (2009) says that design thinker possesses a posture that seeks the unknown, and adopts the possibility of surprise, being comfortable wandering inside the complexity, without knowing what's on the other side. This posture of the designer thinker takes the balance between validity (produce results that reach certain goal) and reliability (produce consistent and predictable results), explicitly seeking the validity, without eliminating the reliability. We can say that design Thinkers challeng the status Quo.

Other Design Thinker attitude according with Chas Martin (apud Chohan, 2008) is the long-range vision of design thinker, and this is something that can't be taught, but can be involved in the culture that respect and lets people take risks, make mistakes, and go up to the limits of expectations. The ability of the designer of taking risk helps the organization to adopt innovative postures.

It seems that the behavioral and cognitive skills of innovators are the same of the design thinkers skills. Brown (2009) affirm that the design thinking begins with the skills that designers have learned over time, such as: to align the needs of humans with the technological resources available in the organization; on intuition; the ability to recognize patterns; build ideas which have meaning as much emotional as functional; the ability to question the surroundings and be empathic; and the ability to express themselves differently than by words or symbols. That last one of the most important designer's skills, because "the act of drawing seems to clear the designer thoughts" (Mozota, 2003), because the design process, it seems, is hard to drive by purely internal mental processes; the designer needs to interact with an external representation. 
There's a cognitive limit to the amount of complexity that a person can handle internally; sketch provides a temporary and external storage for the ideas tried and that externalization supports the dialogue that the designer has between the problem and the solution.

The design thinkers uses the design process as much as a critical process, as discovery. He uses drawing as a means of materialization, imagination, or discovery of something that cannot be built on his mind, and also as a means of communication with the other. Cross (2007) states that in these cases, the design process becomes not only a personal but a cognitive process, such as a shared and social process. This process leads to another skill that, according to Brown (2009), is the ability to work in an interdisciplinary way and create networks.

Pinheiro and Alt (2011) claim that the design thinker in order to work in an interdisciplinary way creates islands of visual information that are available throughout the project, allowing the team to navigate without losing the line of reasoning. These islands create spaces of co-creation, which is a form of innovation that happens when people from outside the company as suppliers, employees and customers works with the business or product innovation (Fraser, 2012).

The visual codes developed by the design thinker, when specifying the externalized knowledge, facilitate collaboration on projects. He observes the ordinary and writes his observations and ideas visually.

Fraser (2012) claims that the fastest way to communicate is usually through vision. If drawing a diagram and mapping a system of parts and interrelated forces, for showing a discussion, challenge or solution, it brings clarity and focus at communications and collaborative efforts.

The culture of design thinking encourages the prototype, which is a way of thinking visually. For a design thinker, the prototype is not only a way to validate ideas, but is also a creative process. The only premise is that prototypes need to be testable, but not necessarily physical. Brown (2009) claims that prototypes can be storyboards, scenes, movies, and even a theatrical improvisation.

Competent practitioners of design thinking usually know more than can say. They demonstrate a kind of know-in-practice, it is mostly tacit knowledge. They identify a cognitive process of reflection-in-action as the intelligence that guides the behavior "intuitive" in practical contexts of thinking and acting, something like "thinking on your feet"'. Reflect-in-action is an experimental framework in which the design thinker finds a way to view the problem with the hands, in the form of prototypes.

The empathy is another very important skill of design thinker, especially in the early stages of the project, when the designer acts in the socio-cultural context as interpreter of the user and their relationships in this context. For Fraser (2012) empathy is to be able to see and feel what others see and feel, leading to a deeper understanding of the opportunity to meet the demands.

Kelley (2005) affirms that the design thinker has another skill, is the ability of cross-pollinate, according with the author they have the childlike ability to see patterns that others can't, and spot keys differences, however they also have a very adult skill, they think in metaphors, enabling them to see relationship and connections others miss. They act as a matchmakers, creating unusual combinations that often sparks innovative ideas. They are able to see the problems by another angle.

We can see the similarity between the skills and attributes of design thinker with the innovative DNA. The table 5 below demonstrate this relationship. 


\begin{tabular}{l|l|l|l|}
$\begin{array}{l}\text { Design Thinker Skills } \\
\text { and Attitude }\end{array}$ & $\begin{array}{l}\text { Behavioral Skills of the } \\
\text { innovators } \\
\text { Emphatic Observation } \\
\text { Questioning }\end{array}$ & $\begin{array}{l}\text { Cognitive skill of the } \\
\text { innovators }\end{array}$ & $\begin{array}{l}\text { Courage of } \\
\text { innovate }\end{array}$ \\
\hline Collaboration & Networking & & \\
\hline $\begin{array}{l}\text { Generates Prototypes } \\
\text { Visual thinking }\end{array}$ & experimenting & & \\
\hline $\begin{array}{l}\text { Cross-pollinator } \\
\text { Creative }\end{array}$ & $\begin{array}{l}\text { Associational } \\
\text { Thinking }\end{array}$ & \\
\hline $\begin{array}{l}\text { work with diferenciation } \\
\text { Vision of the future }\end{array}$ & & & $\begin{array}{l}\text { Challenguing the } \\
\text { status Quo }\end{array}$ \\
\hline \begin{tabular}{l} 
Taking risk \\
\hline
\end{tabular} & & & Taking risk \\
\hline
\end{tabular}

Fig, 5. Comparison between the skills and attitudes of design thinker with the Innovator's DNA. Source: Demarchi, Fornasier, Ortuño e Marquina (2014, p. 3231)

The design thinking helps in insertion of the design driven innovation using the his full potential of the designer to identify patterns, co-create, and generate re-significations, through visual codes, using its more important skill - the visual thinking.

\section{Strategic Integrator Design Management enhanced Model (SiDMe)}

The SiDMe model is divided into strategic, strategic/tactical and operational Design, covering the conversion/production of knowledge and integration of knowledge. The model has seven spaces (the eighth is still in phase of study and has not yet been outlined) and they overlap three cycles of divergence and convergence. This article will work with the spaces relative to the knowledge production, consisting of 5 spaces, as shown in figure 6 . 


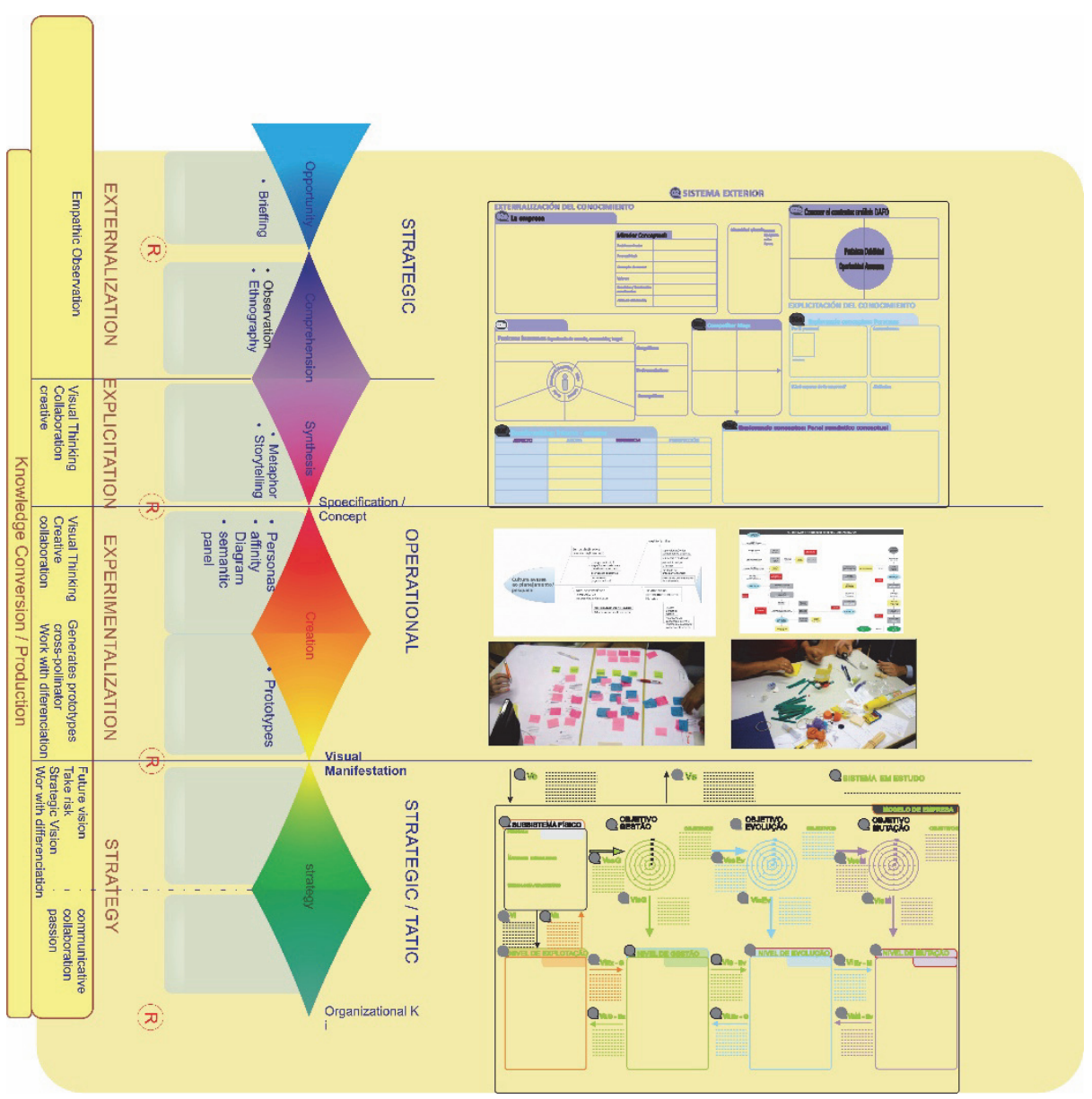

Fig. 6. Strategic Integrator Design Management enhanced Model (SiDMe) with techniques

The model is based on design thinking and through the use of certain techniques emphasizes the skills of design thinker. The demonstration of its uses in this article will be in business design.

The model was applied in various organizations, by the SiDMe Model. and its research group at the University State of Londrina, through a survey of exploratory nature, using the delineation ex-post-facto, we could understand the importance of using visual codes for the explicitation of knowledge, assisting the process of sharing and learning knowledge throughout the research group , generating a process of cocreation. In this article will be shown the model application during the laboratory service organizations.

The first cycle of divergence and convergence starts with empathy for others and with significant understanding of the people and what is important to them, so profound and complete. Despite market reports and quantitative surveys provide a good measure of habits, and customer values, most of these relationships are tacit and cultural knowledge, therefore need to be externalized through the empathetic observation.

First happens occurs the divergent, that can be the path to innovation, which first extends the knowledge of the universe to be worked, analyzes the knowledge and information raised, then synthesize usually guided by techniques such as metaphor and/or analogy, then starts the convergent thinking.

The opportunity is triggered by the company, when its feel the need to change and search at the design the opportunity to innovate. Is set a briefing with basic information obtained with the strategic repository, here happens the first knowledge's reduction. The company checks a dissonance in the organization and 
seeks someone to understand it. In the case of organizations presented here, they sought SiDMe Model. to help them with their problem.

The comprehension space objectively define the scope of the project and its borders, and will identify the profiles of users and other key actors that should be covered, when it will be possible to check which areas of interest that should be explored and provide inputs for the elaboration of the themes that will be investigated, when occur the deep immersion of the designer in the organization. Here the designer uses several techniques to help externalizating and emphasize the skills of empathic observation and intuition of design thinker.

The group went to the field, visited the organization in an attempt to sympathetically understand the organization, spent a few hours with the organizational team understand their wishes, filmed conversations, took photos and worked with members of organizations in the construction of some applied techniques as shown in Figure 1.
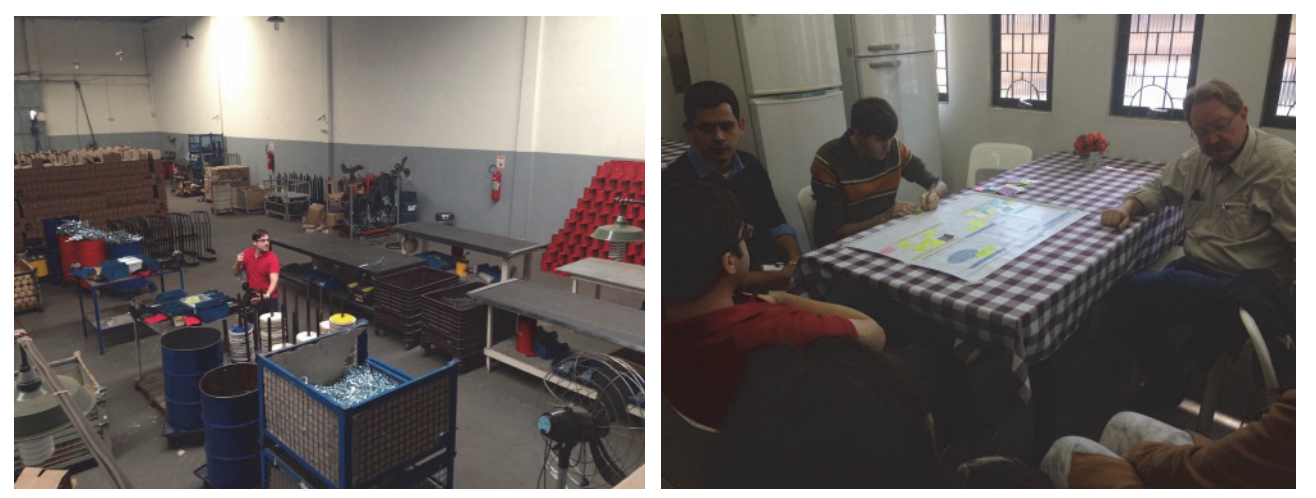

Fig. 7. Organizational member demonstrating how the organization works and working with the group in the construction of some visual manifestation

Once impregnated of their concept by means of convergent thinking, the designer starts the synthetic space by the storytelling and visual thinking to extract meaningful patterns from a mass of raw information, fundamentally is a creative act, giving rise to another knowledge's reduction. Once again it is necessary the use of various techniques of knowledge's explicitation applied through visual thinking, creative and intuitive skills.

The group initiates the synthesis and the knowledge's explicitation using visual techniques to share knowledge with the group, and then start the creation space.

The design operational process begins in the space of creation, when the designer uses all their explicit and tacit knowledge aggregated by creative and experimental skills, and converts the concept in objective knowledge. Here begins another cycle of divergence and convergence, which the designer expands creative techniques to then synthesize and reduce, using experimental and collaborative skills from several types of prototypes.

This second cycle is where generated innovative solutions that will contribute to a better experience. This requires that the designer is open to exploring new possibilities, including those that are outside of the existing paradigm.

Here was felt the need to use new visualization techniques for the generation of ideas. It was noticed that the techniques used by the SiDMe Model didn't have a board for this step, and that most of the time was used empirically techniques based on the experience of the researchers, trying to build joint solutions using first the fish bone technique to find the causes for the problems encountered and for creating 
solutions: the brainstorm; insight cards, affinity diagrams. For a joint construction of the solutions were used prototypes of Lego and other materials, as shown in Figure 2.

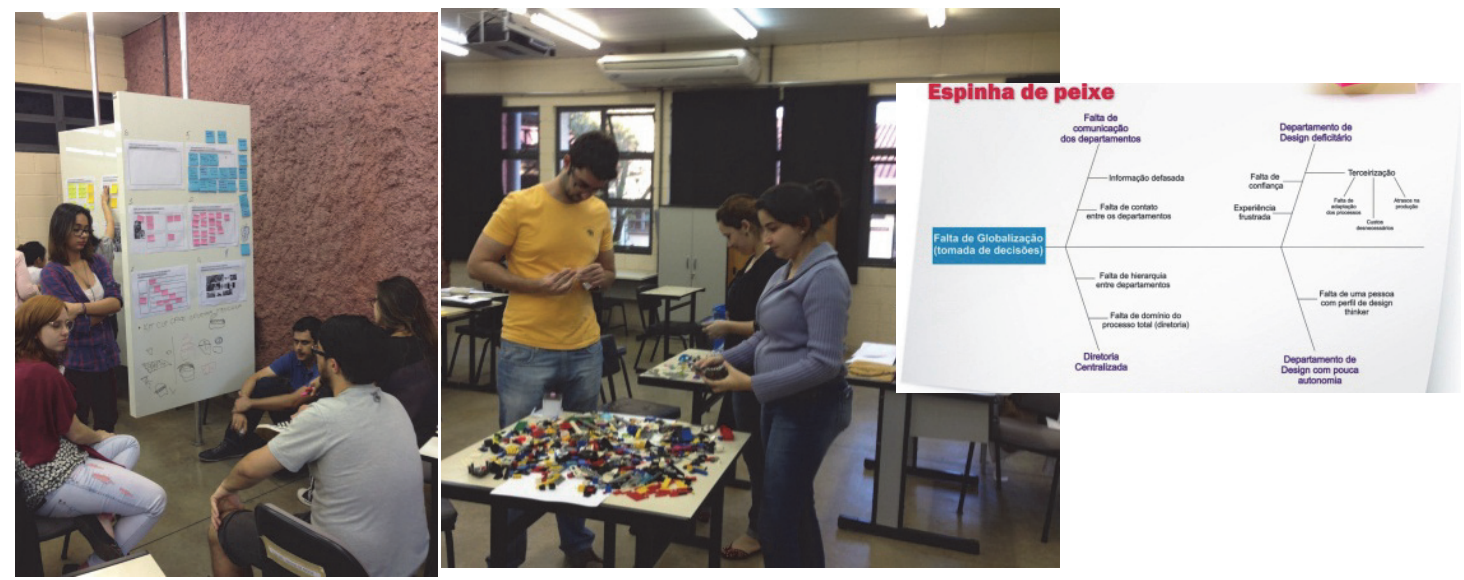

Fig. 8. Team working with different techniques in the search for solutions

In the third cycle happens the strategic actions when the designer, by his future vision, creative, posture to take risk and collaboration skills, develops proposals for strategies applications a document entitled SiDMe Model (strategic plan) in a cycle of divergence and convergence and terminates the production of knowledge by the fourth knowledge's reduction as shown in Figure 3.

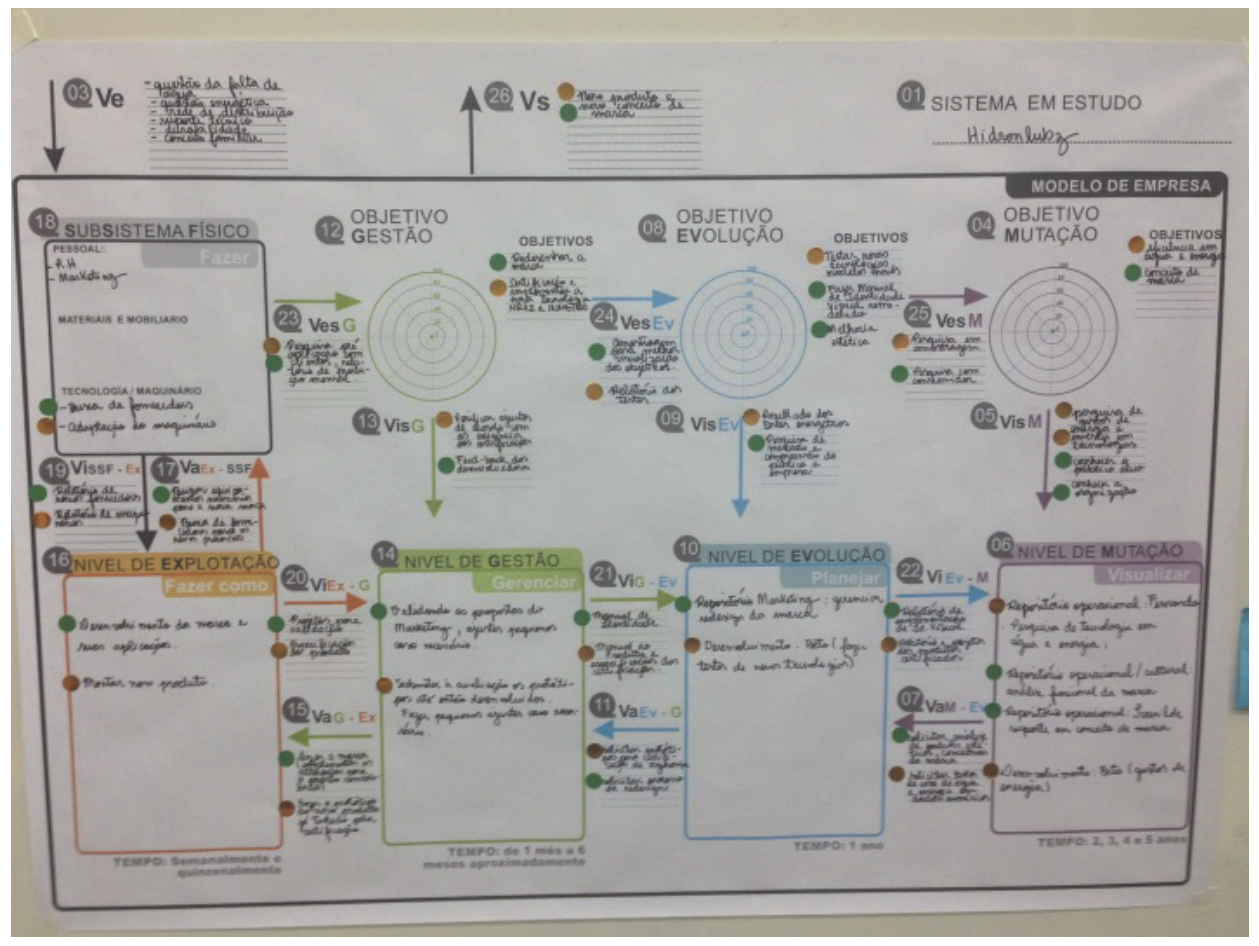

Fig. 9. Completed model within strategic actions 


\section{Conclusions}

After the application of the model it is evident that the SiDMe is a conceptual model that allows the application of Design Thinking through the use of visual techniques impregnated with visual codes.

We can verified that in each space is used techniques of visual preference, and that these were pre select preference techniques and placed on informational board. The LabConde uses a device called IdThink for the spaces of understanding, synthesis and strategic actions, however realized that it will be necessary to develop a device for creating space to assist in explicitation and generation of solutions to the problems of the organizations in a creatively and collaborative way.

Considering the bases of design driven innovation, revolving around the sharing of knowledge obtained from users and their relations, taking into account socio-cultural systems have not yet established, the SiDMe model, aggregate of devices of explicit knowledge based in visual codes, can assist the insertion of this process in the Brazilian organizations. Through visual codes model, which emphasizes the skills of design thinker, helps the process of sharing and learning in the process of co-creation.

A study of Forrest Research cited by Fraser (2012) highlights the attraction of Brazilians by social networks, primarily in conversational and criticizes level. The high degree of interaction with companies that use social networks; and the natural predisposition of co-creating with them, is a sign that Brazilians have pre disposition to co-create. The research also states that $75 \%$ of Brazilians online are classified as co-creators volunteers.

Considering technology as knowledge, then, the innovation of knowledge is responsible for cultural exchange: it depends on the culture and generates culture, as a cycle. Culture is a historically transmitted pattern of meanings embodied in symbols, a system of inherited conceptions expressed in symbolic forms by means of which men communicate, perpetuate, and develop their knowledge and their attitudes about life (Geertz, 1989).

So the ID-Think is a fertile land for the implementation of design driven innovation and the skills of design thinkers is a greater tools to assist organizations to adopt it. The design thinker through their skills evidenced by SiDMe model helps the organization to access and internalize knowledge design discourse, assisting in building links between the different socio-cultural worlds and industries, and thus facilitating the transfer of knowledge of meanings and languages between different contexts.

\section{References}

BROWN, Tim. (2009). Change by design: how design thinking transforms organizations and inspires innovation. New York: HarperCollins,.

CHESBROUGH, H. (2012). Inovação Aberta: como criar e lucrar com a tecnologia. Porto Alegre:. Bookman.

CROSS, N. (2007). Designerly ways of knowing. Boston: Birkhauser verlag AG.

DEMARCHI, A.P.P., FORNASIER, C.B. R., MARTINS, R.F.F. (2013). Strategic Integrator Design Management Model Enhanced. In Proceedings of International Conference on Integration of Design, Engeneering and Management for Innovation- IDEMI. Florianopolis: IDMEC, vol.1, p. 201-209.

DYER, J., GREGERSEN, H., CHRISTENSEN, C. (2011). The innovator's DNA: Mastering the five skills of disruptive innovators. Havard: Havard Bussiness Review Press.

FRASER, H. (2012). Design para negócios na prática. Rio de Janeiro: Elsevier.

GEERTZ, C. (1989). A interpretação das culturas. Rio de Janeiro: Guanabara.

KELLEY, T \& LITTMAN, J. (2005). The ten faces of innovation. USA: Doubleday.

MARTIN, R., (2009). The design of business: Why design thinking is the next competitive advantage. Boston: Harvard Bussiness Press. 
MORACE, F. (2009). Consumo Autoral: As gerações como empresas criativas. São Paulo: Estação das Letras e Cores.

MOZOTA, B. B. (2003). Design Management: Using to build brand value and corporate innovation. New York: Allworth Press.

NORMAN, D., \& VERGANTI, R. (2012), Incremental and Radical Innovation: Design research versus Thecnology and meaning change. Design issue, vol. 27, p. 1167-1180.

PINHEIRO, T. (2011). Design Thinking Brasil. Rio de Janeiro: Elsevier.

ROMANINI, V. (2008). Design como comunicação: uma abordagem semiótica, Design: Quo Vadis? Anais do I Seminário do Cursos de Design da FAUUSP. São Paulo: FAUUSP. Vol. 1, p. 75-80.

GAY, P. du, et al (1997). Doing Cultural Studies: The Story of the Sony Walkman. Sage.

TERRA, J. C. C. (2007). Inovação: quebrando paradigmas para vencer. São Paulo: Saraiva.

VERGANTI, R. (2010). Design, meaning and radical innovation: meta-model and research agenda. In Jornal of Product Innovation Management, vol. 27, p. 1167-1180.

XAVIER, C. M. S. (2014). Gerenciamento de projetos de inovação, pesquisa e desenvolvimento de produtos. Rio de Janeiro: Brasport. 